Intersections

Canadian Journal of Music

Revue canadienne de musique
Intersections CANADIAN JOURAL OF MUSIC

\title{
A Synthesis of Animation and Jazz in Begone Dull Care
}

\section{Heather Pinson}

Volume 37, numéro 2, 2017

URI : https://id.erudit.org/iderudit/1066620ar

DOI : https://doi.org/10.7202/1066620ar

Aller au sommaire du numéro

\section{Éditeur(s)}

Canadian University Music Society / Société de musique des universités canadiennes

ISSN

1911-0146 (imprimé)

1918-512X (numérique)

Découvrir la revue

Citer cet article

Pinson, H. (2017). A Synthesis of Animation and Jazz in Begone Dull Care. Intersections, 37(2), 101-122. https://doi.org/10.7202/1066620ar

\section{Résumé de l'article}

En 1949, les cinéastes Norman McLaren et Evelyn Lambart ont réalisé le court métrage d'animation de sept minutes et quarante-huit secondes intitulé Begone Dull Care, à partir d'images abstraites défilant au rythme de la musique du trio d'Oscar Peterson. Dans ce film tripartite, McLaren et Lambart tirent parti de la nature improvisée du jazz pour établir un récit, permettant aux formes animées de répondre et réagir à la musique elle-même. Cet article s'intéresse à la collaboration entre artistes et musiciens dans le but de créer d'une telle oeuvre, et examine les relations interdisciplinaires entre musique et animation dans Begone Dull Care.
Copyright @ C Canadian University Music Society / Société de musique des universités canadiennes, 2019
Ce document est protégé par la loi sur le droit d'auteur. L'utilisation des services d'Érudit (y compris la reproduction) est assujettie à sa politique d'utilisation que vous pouvez consulter en ligne.

https://apropos.erudit.org/fr/usagers/politique-dutilisation/ 


\title{
A SYNTHESIS OF ANIMATION AND JAZZ IN BEGONE DULL CARE
}

\author{
Heather Pinson
}

In 1949 filmmakers Norman McLaren and Evelyn Lambart created the seven-minute, forty-eight-second, thirty-five-millimetre animated short Begone Dull Care, featuring abstract images moving in time to the music of the Oscar Peterson Trio. Given a Special Genie Award for experimental filmmaking, McLaren and Lambart highlighted music, in this three-movement film, as what propels the animation rather than the more traditional role of supporting moving images. They created the illusion that music is a driving factor for the arrangement, organization, and manipulation of the images, thereby intensifying the interaction between picture and sound. As a result, the film contains animated images and shapes that seem to respond and react to the music itself. This characteristic of implied spontaneity is often found in McLaren's films; however, Begone Dull Care's particular charm lies in its nuanced relationship between the music and anthropomorphic images that display human characteristics and seem to engage with and react to the improvised sounds of jazz-Not to mention, the images in Begone Dull Care dance to one of the most famous piano players of the twentieth century, who was relatively unknown when this film was made.

Although McLaren is not the first filmmaker to purposely integrate visual and aural form, he is one of the few artists, along with Lambart, who painted directly onto the celluloid itself and then sync the film to the music, instead of vice versa. He used a static means of artistic expression (painting) substantiated in a moving format (film) to create the appearance that abstract, animated objects are reacting to the music "they" hear. This article has three main goals: (1) to briefly explicate the circumstances on how this short but influential film came to be, (2) to address McLaren's and Lambart's ingenuity of filmmaking as described in their words and those of their scholars, (3) to examine how animated objects are represented through movement, rhythm, colour, shape, and sound in the first movement and credits of the film. While it would be fascinating to examine the musical and visual relationship throughout all three movements of this film, the author selected only the first movement, the title, and ending credits here for analysis, calling for future authors to explore the remaining movements. 


\section{Collaboration between MCLAREn, LAmbart, AND Peterson}

Born in 1914 in Stirling, Scotland, McLaren studied set design at the Glasgow School of Art. He had a love for music and fondly remembered listening to radio broadcasts as a child. While in school, he believed that film had yet to fully come into its own, and that research and experimentation were the natural ingredients of artistic creation. In 1939 McLaren travelled to New York City, and in 1941 he moved to Canada to work for the National Film Board at John Grierson's invitation. He opened an animation studio and began to train Canadian animators such as Evelyn Lambart, with whom McLaren found a professional partner and collaborator (Mollaghan 2015, 112).

Also born in 1914 but in Ottawa, Evelyn Lambart began to lose her hearing at the age of six and had a difficult childhood without the benefit of a hearing aid. As a result, she honed her artistic studies and, after graduating from Ontario College of Art, became one of the National Film Board members in 1942 and Canada's first woman animator. "[John] Grierson offered her a position with a small team of animators led by Norman McLaren" (McWilliams 2017). One of her early assignments was to animate the maps featured in the documentary series The World in Action. She also practised her own paint-on-glass technique, which would soon become one of her specializations, and while working on McLaren's Now Is the Time (1951), Around Is Around (1951), and Twirligig (1952), she helped pioneer stereoscopic (3D) animation.

McLaren and Lambart shared ideas and opinions as a part of their collaboration from 1944 to 1965 . Lambart was the methodical one and cultivated much of the design, colour, etchings, and even dope sheets. "She began as his assistant, and their collaboration soon grew into a true partnership that saw her credited as co-director of the films they developed together. McLaren owed Evelyn a great deal: she displayed uncommon practical wisdom and prodigious dexterity-two qualities that made her an indispensable colleague. With McLaren, she co-directed the Rythmetic (1956), Lines: Vertical (1960), Lines: Horizontal (1962) and Mosaic (1965). But their greatest work, inarguably, was Begone Dull Care (1949)" (McWilliams 2017). Since McLaren couldn't decide how to end the third movement, Lambart finished up the last thirty seconds or so on her own.

Lambart admitted that this was her favourite collaboration with McLaren. But even though she is credited as a full co-creator of the visuals in Begone Dull Care with McLaren, many writings on the film emphasize McLaren and his drawn-on process as his contribution. While there is no malice in leading with McLaren's talents first, women filmmakers continue to struggle to find the same recognition as their male counterparts. In addition, Lambart herself remained more reserved about her own skill set, quietly speaking from behind the scenes. In fact, it wasn't until 1965 that Lambart decided to start her own solo film career but grappled with this decision for a while. In the Eleven Moving Moments with Evelyn Lambart documentary, she recalled it was Wolf Koenig ${ }^{1}$ who said, "Come on Eve, you need to make some films of your own."

\footnotetext{
1 Wolf Koenig was cameraman and director and head of the NFB English animation studio.
} 
Lambart continued, "It was a bit of a stretch for me to realize that my opinion mattered. See I was so accustomed to discussing everything with Norman and coming to a consensus about something, and suddenly, I had to make all of my decisions myself" (McWilliams 2017). Lucky for her viewers, Lambart was able to work jointly with McLaren and as a solo artist during her thirty-year career at the Film Board.

As relatively new to the professional jazz world, Oscar Peterson was an upcoming pianist in the late 1940 s performing in his native Canada. As indicated in Terence Dobson's The Film-Work of Norman McLaren and the Film Board's seven-DVD set on McLaren, the filmmaker heard the twenty-four-year-old musician on record and travelled from Ottawa to Montreal to see the Oscar Peterson Trio perform in a club near Windsor Station. At the club, McLaren asked if Peterson would be interested in recording the music for an abstract film McLaren was working on. ${ }^{2}$ The following morning, the musicians met McLaren at the National Film Board and watched McLaren's Stars and Stripes (1939) and Dots (1940) and Loops (1940), telling McLaren they understood perfectly what was needed. Returning to the club, Peterson played some ideas as a response to what he saw in the film. Since McLaren was concerned with paying royalties for well-known themes, Peterson mulled only on improvised passages for McLaren to choose: "One of them I liked very much so I said, 'Let's develop this one,' and we started expanding the tune. I started making suggestions because some of the things he was doing gave me ideas. There were stretches where it was too hectic for too long a time. The eye would be tired with a fast movement, so I said, 'Calm that down. Make it slow for this part or that part.' And he'd do it'" (McLaren, quoted in Collins 1998, 76. See also Dobson 2006, 202; and Elley 1974, 94-102).

Peterson monitored their progress by writing on the back of an envelope that lay on the piano; and over the next four days, Peterson shaped the music into a form to which McLaren could animate. The group met at the recording studio two weeks later, and when the Oscar Peterson Trio rehearsed the whole piece, McLaren noticed little from their original session, acknowledging that "Oscar Peterson is a born improviser." McLaren said they spent the first hour of the recording "trying to partly get it [the music] back to its original shape, while preserving the good, new things [Oscar] had improvised" (McLaren in "Interview" 1977, 25, quoted in Dobson 2006, 203).

The soundtrack to Begone Dull Care was not included in any of Peterson's albums at the time, nor do his biographies list the performers of this short film. Peterson is most known for the Oscar Peterson Trio formalized in the 1950s,

2 This partnership makes this short film one of McLaren's most discussed, as found in Dobson (2006, 200-7); Richard (1982); McWilliams and Dionne (1990), and finally McLaren (2007). The recognition of this abstract film can also be seen in "McLaren Wall-to-Wall" celebrated in Montreal at the 10oth anniversary of McLaren's birth in 1914. As a part of the celebration of his life, seven original video works inspired by McLaren's films were projecting on the facades of buildings in Montreal's entertainment district. Japanese artist Mirai Mizue based his film The Baby Birds of Norman McLaren on Begone Dull Care and depicts the metamorphosis of various white animals on a coloured and animated background. More information about this project can be found at http://mclarenwalltowall. com/en/. 
which included Ray Brown on bass and Ed Thigpen on drums, but he recorded in Montreal with two other trios in 1947: one group was with Austin Roberts (or "Auston" as Peterson spelled it) on bass and Clarence Jones on drums, and another group was with Mark "Wilkie" Wilkinson on bass and Albert King on drums (Palmer 2002). ${ }^{3}$ There is some confusion as to who recorded the soundtrack for Begone Dull Care (Melançon 2005); however, as indicated in Meeker $(1977,149)$, Austin Roberts on bass and Clarence Jones on drums were on record for McLaren's film.

\section{The Filmmaking Process of Begone Dull Care}

Since McLaren asked The Oscar Peterson Trio to record the music before the film was made, McLaren and Lambart took the opportunity to draw or paint on the film as a response to the music, thus the abstract images appear to be responding to the music spontaneously: "It's the movement in the music, not particularly the instrumentation or colouration or harmony. The movement is the common denominator between the picture and the sound" (Collins 1998, 40). But how did McLaren and Lambart accurately capture the movement of the music on film? The difficulty is found in timing the rhythmic duration of the notes to the moving images painted on the celluloid. McLaren and Lambart manipulated the film stock itself, a technique which has several iterations and descriptive properties but is known mostly as direct animation. ${ }^{4}$ However, what ended as a smartly crafted form of artistic production started as a necessary means to overcome the lack of funds. While working on Dots and Loops, McLaren did not have money for a camera, thus decided to make a film by drawing or painting his visuals directly onto the clear film-stock. He worked with Lambart, talented in illustration herself, to improve upon this method for Begone Dull Care.

First, the recorded music was measured on the same clear celluloid strip of film used to draw the images. By using an oscilloscope, McLaren and Lambart could see the vibrations and mark them on clear film. In figure 1, McLaren is approximating pitch of his own to run through a moviola as a demonstration of how one can witness sound qualities in music.

After measuring notable musical passages, entrances, and exits as a visual map, the filmmakers would match

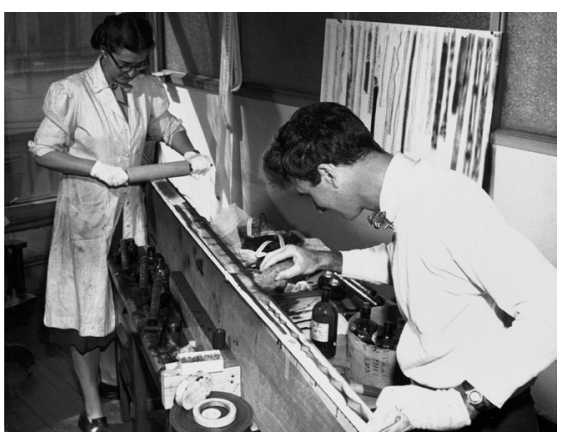

Figure 1. Begone Dull Care (C) 1949 National Film Board of Canada. All rights reserved.

3 For other sources on Peterson's personnel and history, see Lees (2008), and Barris (2002).

4 This technique is also known as drawn-on-film animation or animation without camera. For more information on the direct animation technique, see Furniss (2007). Other examples of this method-McLaren's Fiddle-de-dee, Short and Suite, Hen Hop, and Blinkity Blank-are hand-made abstract fantasies. For more on McLaren's elements of line and visual rhythm in film, see Warkentin (1988). 
their own configured shapes and colours to follow the benchmarked sounds. McLaren worked over a ground glass area with light shining through the glass and used an individual grid behind each frame as a reference (Richard 1982, 31). Both filmmakers worked directly to the film and viewed the painted strips through a moviola with the music playing in the background. They worked jointly on short sections of the film, but "used what was most suitable for the film. So I divided the music into pieces and I painted on the film placed on a big table, using a moviola. After having 'painted' four or five 'seconds,' Evelyn Lambart and myself put on the visual film and the sound tape together, to see what the effect would be. If it did not work, we would repaint or move onto different attempts. It was a very satisfying and very pleasant way of working" (Dobson 2006, 203).

We made Begone Dull Care in shots, as it were, the shots being defined by the length of the musical phrase. We'd do maybe five or six versions, after which we'd run them on the moviola and choose the best. Some were painted as the moviola was moving, and we'd dance the brush full of paint to the rhythm of the music in the picture-gate. All the middle-section with the little white dots on black ... that was done with a knife on black emulsion running through the moviola, going tick-tick-tick in step with the music, but running about half speed. (Collins 1998, 40)

After working in four- to five-second segments, McLaren and Lambart would check to see if their drawings had captured the "spirit of the music" (McLaren cited in Mollaghan 2015, 115; and Dobson 2006, 207). If they did not, McLaren and Lambart would repaint the images, mirroring the collaborative process performed by the musical trio. "This approach means that they did not try to find a visual equivalence for every note, allowing scope for improvisation within the visual imagery" (115). It was not only the filmmakers who created and adapted images to Peterson's music; Peterson also shaped his composition, through his trio, to the work and guidance that the filmmakers provided during their meetings and recording session.

There was much give-and-take between us, in the sense that Peterson often did things on the piano that for me gave rise to new visual ideas; on the other hand, I had already certain visual ideas which dictated that he do certain things in the music. From his abundant improvisation I was able to select from and arrange ideas that would inspire us when I and Evelyn Lambart came to make the picture. The shaping of the music evolved almost bar by bar, and certainly phrase by phrase.... The music was measured, note by note, phrase by phrase, etc. The measurements, transferred to a "dope-sheet" which charted the music on paper. The measurements were numbered, and these numbers were marked on the $35 \mathrm{~mm}$ celluloid, between the sprocket holes and along the edge of the film. (McLaren 2006, 5)

\section{Continuing to reference Begone Dull Care, McLaren stated,}

The clear celluloid was stretched out and pinned down to a very long narrow plank of wood (over $12 \mathrm{ft}$. or 4 meters long). In a various ways, almost 
too many to list, we applied all kinds of transparent coloured dyes, and scratched or engraved on them. One basic way was to apply a different colour to each side of the film, for the following reason. A flat wash of yellow on one side and blue on the other side gave us an overall green ground; engraving on the yellow side produced a blue pattern, on the blue side a yellow pattern. (McLaren 2006, 5)

Generally, in the first and third parts [of Begone Dull Care] the frameline was disregarded; we tended to treat the visuals in metrical lengths of textured patterns corresponding to the paragraphs and sentences of the music. However, sudden musical accents or short phrases were emphasized by additional painting or engraving, in which case the actual frames of the film were taken into account. In certain solo percussion sections we engraved on black film, individual frames with clearly defined images being synchronized with musical beats. In the still other sections, painting with a full brush of wet dye was applied as the films moved through the gate of a moviola, the brush being moved to and fro, up and down, or pressed in and out, from its base to its tip, in rhythm to the music, which was run interlocked in the sound-gate of the moviola. (McLaren 2006,6)

McLaren enlisted the help of Lambart to arrange the film and tape it together, repaint, or adjust as they went along. They used India ink, watercolour, cell paint, dust, "dyes with big and little brushes, with stipple brushes, with sprayers, with finely crumpled paper, and with cloths of various textures. We pressed dry textured fabrics into washes of still wet dye. Netting, mesh and fine lace were stretched out tightly in various ways against the celluloid, to act as stencils when dye was sprayed on the film. Different types of dust were sprinkled on wet dye, which formed circles as it recoiled from each dust speck. We found a black opaque paint which, as it dried, created a crackle pattern" (McLaren $2006,6)$. By drawing onto the film and using a variety of tools and techniques at their disposal, they had maximum control of the visual-audio relationship, and the result is seen as restless lines and shapes that are constantly moving in a camera-less and frameless projection (Richard 1992, 70).

"Because the soundtrack ... is composed of largely percussive rhythms and repetitive, very short melodic phrases, McLaren's flashing imagery is episodic, achieved by a combination of painting on clear $35 \mathrm{~mm}$ leader and by scratching on black leader (both across frames and frame by frame)" (Husbands 2014). McLaren steered away from more traditional methods of filmmaking that included photographing the objects frame-by-frame with an animation camera and was one of few filmmakers who embraced camera-free animation. He wanted the illusion of being totally frameless, and he enjoyed the freedom to ignore the frame divisions, for the most part, as he had done in a previous film, Fiddle-de-dee (1947). By ignoring frame lines in Begone Dull Care, McLaren manages to infuse the images with the frenetic energy of Peterson's composition. His disdain for frame boundaries also contributes to the unique qualities that make his films so effective as works of art; bringing the viewer in, yet out of the confines of the film frame, thereby interacting with the viewer and playing with the viewer's expectations (Pochodowicz 1998). 
There were many advantages of the direct-drawing on the film stock: first, it permitted the filmmakers a flexibility and immediate feedback. McLaren could simply run the film through a moviola and could build, correct, or morph as the film developed. Without the use of a script or a storyboard, he could be more spontaneous and change frame-by-frame. It also was a cheaper way, in his early years, to add sound instead of paying for a recording studio and laying sound on the track (Dobson 2006, 163-4). He could control rhythm and tempi and their relation to the visual image (166). The process afforded McLaren a closeness with the film since he often compared the relationship between drawing on film to that of a painter and canvas (163; Dobson 2017, 94). Finally, McLaren and Lambart were able to control both aural and visual aspects of the film without being usurped by other creative or expressive voices. Of course, one would struggle with keeping clear film free from unwanted fingerprints, dust, or other items, thus they often used black film, as seen in Begone Dull Care, which allowed them to scratch or carve into long stretches of film (Dobson 2017, 90).

The use of a moviola as a tool for the timing and sequencing of a scene allowed for immediate feedback. The filmmakers did not have to wait days for film to be processed in a laboratory to see how a sequence or movement was proceeding; they could shape the film as they worked. As a result, McLaren and Lambart modified their images to match Peterson's music and made each frame coincide with the music through duration and movement to maintain a sense of unity. McLaren "had no script, no storyboard, usually only the vaguest of ideas of the whole film. Normally only the next ten or twenty seconds from the point at which he was working took any definite shape in McLaren's mind" (Dobson 2006, 176). Finally, it is important to note that McLaren considered himself a painter in addition to a filmmaker. With drawing as his first formal artistic training, McLaren enjoyed the aspects of painting onto the film strips, using the surface of the film as a substitute for a canvas. "McLaren's directly animated films have an expressive, painterly quality--the marks of the pen or brush are visible" (175). The filmmakers incorporated the spontaneity and kineticism of Peterson's improvisation and began to paint shapes that corresponded to the music. Regardless of the choice of imagery, the filmmakers successfully captured the spirit of the music, an outline of which is provided in the next section.

\section{Analysis of Music and Animation in the Credits and First Movement of Begone Dull CARE}

Similar to music, film is time-based. By incorporating characteristics from one temporal genre into another, McLaren and Lambart simulate those aspects of music that are time-driven into and onto a frozen, stilled frame. Yet the differences between images and music create certain expectations such as an awareness of structure. Begone Dull Care comprises a fast (allegro) first movement, a slow (molto andante) second movement, and a very fast (prestissimo) final section, establishing a three-movement (fast-slow-faster) ABA form. The form 
is one means of structure, as McLaren himself points out, "Many years ago I was confronted with a problem regarding abstract film visuals. It is relatively easy to make a one or two minute abstract film that will hang together and be a unity. But with an eight or ten minute abstraction, it is much more difficult. One runs the risks of creating either too much monotony, or too much diversity. Some kind of format or structure seemed necessary to vary the uniformity of to discipline the variety. I found that some of the forms which music has evolved (to solve the same problem) lent themselves to abstract visuals. I used the ABA form of European classical music in Begone Dull Care and Spheres, and a short rondo-like form in Short and Suite" (Mollaghan 2015, 113-14; McLaren 1977, 25; and Dobson 2006, 204).

Begone Dull Care begins with Peterson playing a ten-measure introduction in 3/4 time (a sequence pattern descending by half step), followed briefly by Roberts playing an improvisatory bass line. Even these short phrases of music enhance the film in the opening credits, which contains varying titles in seven languages: English; French "Caprice en Couleurs" [Caprice in colours); Spanish "Fantasía en Colores" [Colour fantasy; Hindi "रंग बाहार; Rañga Bāhāra" [Display of colour]; Italian "Capriccio a Colori" [Capriccio in colour); Russian "Красочная фанта́зия; Krasočnaja Fantázija" [Colourful fantasy]; and German "Trübsal Ade!" [Farewell sorrow]-all of which appear, of course, in time to the music. The filmmakers include a scene for each line of credits, "The National Film Board of Canada presents," "Begone Dull Care," "Music by The Oscar Peterson Trio," and "Painting by E. Lambart \& N. McLaren" in these languages, as well as Japanese and Chinese. Following the third movement, the "End" title appears as "fine," but not "fin" in English, and it also includes Italian and Swedish, interestingly; however, a hidden surprise occurs in the race to the conclusion of the film. The word "slut" is slipped in, appearing in sequence with the other languages in the "End" title, and disappears instantaneously. One presumes that there was private joke involved as McLaren scratched this word on the film cell; yet, its purpose is never made known.

There are two other peculiarities in these opening and closing credit lines. One is that McLaren uses different sets of languages for different titles, such as the opening title in English, French, Spanish, Italian, Hindi, Russian, and German, and the ending title in English, Italian, and Swedish. Why does he include so many languages but is not consistent with his selection of languages in the opening and ending credits? Except for those who speak Arabic, Chinese, and Japanese, one is uncertain if the translation is the same in each. Perhaps the words "Caprice en couleurs," "Fantasia en colores," and "Capriccio a colori," all suggest the juxtaposition of musical and visual forms, or more precisely, the rendering of music by colour. The German "Trübsal Ade" comes closest to the English title, but at least the other Western European titles elicit a similar meaning. As a filmmaker, McLaren often includes frequent and playful experimentation with language and imagery; maybe the list of translated languages is another example of "play" for McLaren. In his interviews, McLaren does not provide a rationale for the opening credits of this piece; however, the timing of the credits consistently follows the music is itself an introduction. 
The second peculiarity is that McLaren does not credit himself or Lambart with directing or creating the film; instead the words "painting by" appear to emphasize McLaren's artist ability. Perhaps McLaren is distinguishing the difference between the practice of an artist and that of a filmmaker. As mentioned earlier, he and Lambart painted directly onto the celluloid, effectively replacing the canvas with film and allowing greater flexibility as artists. This frameless animation also frees the artists to draw objects outside of traditional boundaries, thus emphasizing the role as a painter in the credits to yet again break with the traditional role of a filmmaker.

But the music dictates the next sequence of events. Concurrently with the short introduction to the film, Peterson performs a musical introduction, which lasts for approximately sixteen measures. He plays for two bars, followed by the bassist for two bars, both of which are over the root chord of B-flat major. This is repeated three more times while the drummer plays on the off beats with the hi-hat cymbal. The role of Clarence Jones on drums, so far, may seem unimportant; however, his minimalist playing style is not to crowd the busyness of Peterson, as the listener would soon become bombarded with sixteenth notes, fills, and runs from two musicians simultaneously. By laying out and comping only on the quarter- or half-beats, the drummer allows Peterson to provide both the melodic and rhythmic colour to the music.

In overall structural organization, the first movement is arranged into three sections of fast, slow, fast(er). The "head," or melodic theme, of the composition begins with Peterson, who plays the melody underneath a walking bassline.

The first melody line or "A" can be broken into two long phrases that contain two smaller phrases that are repeated. The next phrase labelled as " $\mathrm{B}$ " is only eight measures long, yet the harmonic accompaniment provides some variation for the listener. The first melody line is repeated, followed by a sixteen-measure phrase labelled as "C." In typical jazz fashion, the melody section returns after the improvisation, which completes the layout of the first movement.

Once the theme is established, Peterson takes the lead in the improv section by soloing wildly over the chord changes, pushing the speed of the band members. Jones responds on drums, but only in a restricted role of keeping the offbeat half notes on the hi-hat and occasionally adding fills in the musical space (at the end of a phrase) on brushes. McLaren identified certain colours and shapes for Peterson and for his role in the music: red is typically associated with the upright bass, and black-and-white are linked to the drums. The piano is also associated with horizontal or vertical lines that appear to mimic the strings inside of the instrument.

The main improv section led by Peterson has a white background with a tornado of red and yellow leaf shapes and lines dancing in the foreground. Red, orange, yellow, pink, and purple provide the bright background for the pulsating shapes in black and brown to stand out in the foreground. To indicate the difference in soloing instruments heard in the " $\mathrm{C}$ " section, the background colours swap according to the instrument. Peterson does allow for some musical space, as breaks, for both Roberts and Jones to solo over separately. Trading solos between musicians allows McLaren to create different images 
Table 1. Basic chordal structure and organization for first movement of Begone Dull Care.

\begin{tabular}{|c|c|c|c|}
\hline Introduction & Theme & Improvisation & Return to theme \\
\hline \multirow[t]{5}{*}{$\begin{array}{l}\text { Intro } 16 \text { measures: } \\
\left(B^{b}\right)\left(B^{b}\right)\left(B^{b}\right)\left(B^{b}\right) \\
(F 7)(F 7)(F 7)(F 7) \\
(F 7)(F 7)(F 7)(F 7) \\
(F 7)(F 7)(F 7)(F 7)\end{array}$} & $\begin{array}{l}\text { A1. } 16 \text { measures: } \\
\left(B^{b}\right)\left(B^{b}\right)\left(B^{b}\right)(C F 7) \\
\left(B^{b}\right)\left(B^{b}\right)\left(B^{b}\right)\left(F 8^{b}\right) \\
\left(B^{b}\right)\left(B^{b}\right)\left(B^{b}\right)(C F 7) \\
\left(B^{b}\right)\left(B^{b}\right)\left(B^{b}\right)\left(F 8^{b}\right)\end{array}$ & $\begin{array}{l}\text { A1. } 16 \text { measures: (piano) } \\
\left(B^{b}\right)\left(B^{b}\right)\left(8^{b}\right)(C, F 7) \\
\text { repeated } 3 \text { more times }\end{array}$ & $\begin{array}{l}\text { A2. } 8 \text { measures: } \\
\left(B^{b}\right)\left(B^{b}\right)\left(B^{b}\right)(C F 7) \\
\left(B^{b}\right)\left(B^{b}\right)(F)\left(B^{b}\right)\end{array}$ \\
\hline & $\begin{array}{l}\text { B. } 8 \text { measures: } \\
\text { (A) }(A)\left(A^{b}\right)\left(A^{b}\right) \\
\text { (G) }(G)\left(G^{b}\right)(F 7)\end{array}$ & $\begin{array}{l}\text { B. } 8 \text { measures: (drum solo) } \\
\text { (A7) (A7) }\left(A^{b}\right)\left(A^{b}\right) \\
\text { (G) (G) }\left(G^{b} 7\right)(F 7)\end{array}$ & $\begin{array}{l}\text { Outro: } \\
8 \text { measures }\end{array}$ \\
\hline & $\begin{array}{l}\text { A2. } 8 \text { measures: } \\
\left(B^{b}\right)\left(B^{b}\right)\left(B^{b}\right)(C F 7) \\
\left(B^{b}\right)\left(B^{b}\right)\left(B^{b}\right)\left(F 8^{b}\right)\end{array}$ & $\begin{array}{l}\text { A2. } 8 \text { measures: } \\
\left(B^{b}\right)\left(B^{b}\right)\left(B^{b}\right)(C F 7) \\
\left(B^{b}\right)\left(B^{b}\right)\left(B^{b}\right)\left(B^{b}\right)\end{array}$ & \\
\hline & $\begin{array}{l}\text { C. } 16 \text { measures: } \\
\left(G m^{\sharp} 5\right)\left(G m^{\prime} 5\right)\left(B^{b}\right)\left(B^{b}\right) \\
\left(G m^{\sharp 5}\right)\left(G m^{\sharp}\right)(\text { solo break) } \\
\left(G m^{\sharp}\right)\left(G m^{\sharp}\right) \text { (solo break) } \\
(F, E)\left(E^{b}, D\right)\left(D^{b}\right)(C, F 7)\end{array}$ & $\begin{array}{l}\text { C. } 16 \text { measures: } \\
\left(B^{b}\right)\left(B^{b}\right) \text { (solo break) } \\
\left(B^{b}\right)\left(B^{b}\right) \text { (solo break) } \\
\left(B^{b}\right)\left(B^{b}\right) \text { (solo break) } \\
\left(B^{b}\right)\left(B^{b}\right) \text { (solo break) }\end{array}$ & \\
\hline & & $\begin{array}{l}\text { B. } 8 \text { measures: } \\
\text { (A7) }(A 7)\left(A^{b}\right)\left(A^{b}\right) \\
\text { (G) }(G)\left(G^{b} 7\right)(F 7)\end{array}$ & \\
\hline
\end{tabular}

to accompany the varying sonic textures. These abstract shapes dance, shake, spin, and curl to the sound of Peterson's fingers on the piano as he churns past measure after measure at lightning speed. In one instance, the sounds of the three musicians are encapsulated in a flurry of three-dimensional shapes landing on a pinkish feather; in another, a bird-like design flaps its wings in tempo towards the outro or the ending of a composition. It seems that lateral movement expresses more melodic intervals, and frenzied movement expresses the high energy of the music. "Sometimes the complexity is conveyed by the sustained presentation of an intricate moving pattern, and at other times the complexity is conveyed by simpler images presented in very quick succession" (Dobson 2006, 207).

Another example is the quick trilling of the piano in which "McLaren gives us distorted white comb-like images moving with the music and appearing and disappearing as the trilling starts and stops and starts up again. The soft, muted sound of a string bass is illustrated with roundish, translucent blotches of color and light, accentuated with short, tiny lines coming off from them, like legs on a ladybug, hinting at the strings, but meanwhile maintaining the low, muted feel" (Pochodowicz 1998).

McLaren commented on the musical elements that dictated his choice of images. "I'm very sensitive about dynamics; in a pianissimo passage I will reduce the contrast within the colour or the tones to a minimum, or else keep the movement very small; and vice versa with fortissimo. The thing to do is to go by instinct" (Collins 1998, 40). Thus, when the tempo quickens and the volume rises, the speed of the film and the motion of the colours and shapes on the screen do as well; periods of intense sound are accompanied by lots of colour and flashing light, whereas periods of silence or minimal sound are in sync with a mostly black screen, with only small areas of colour or thin white lines. 

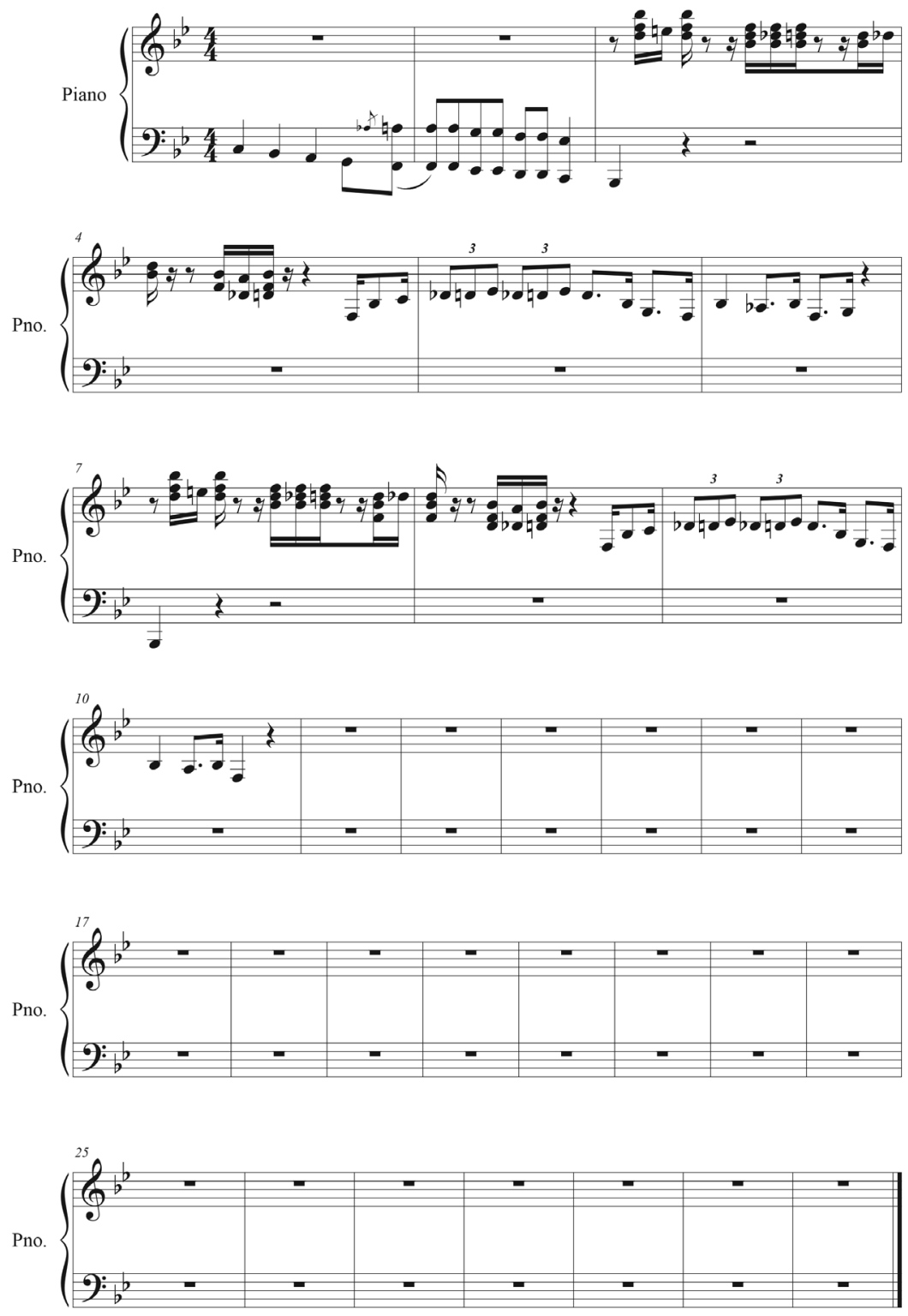

Figure 2. Theme "A" played by Peterson on piano in the first movement of Begone Dull Care. 


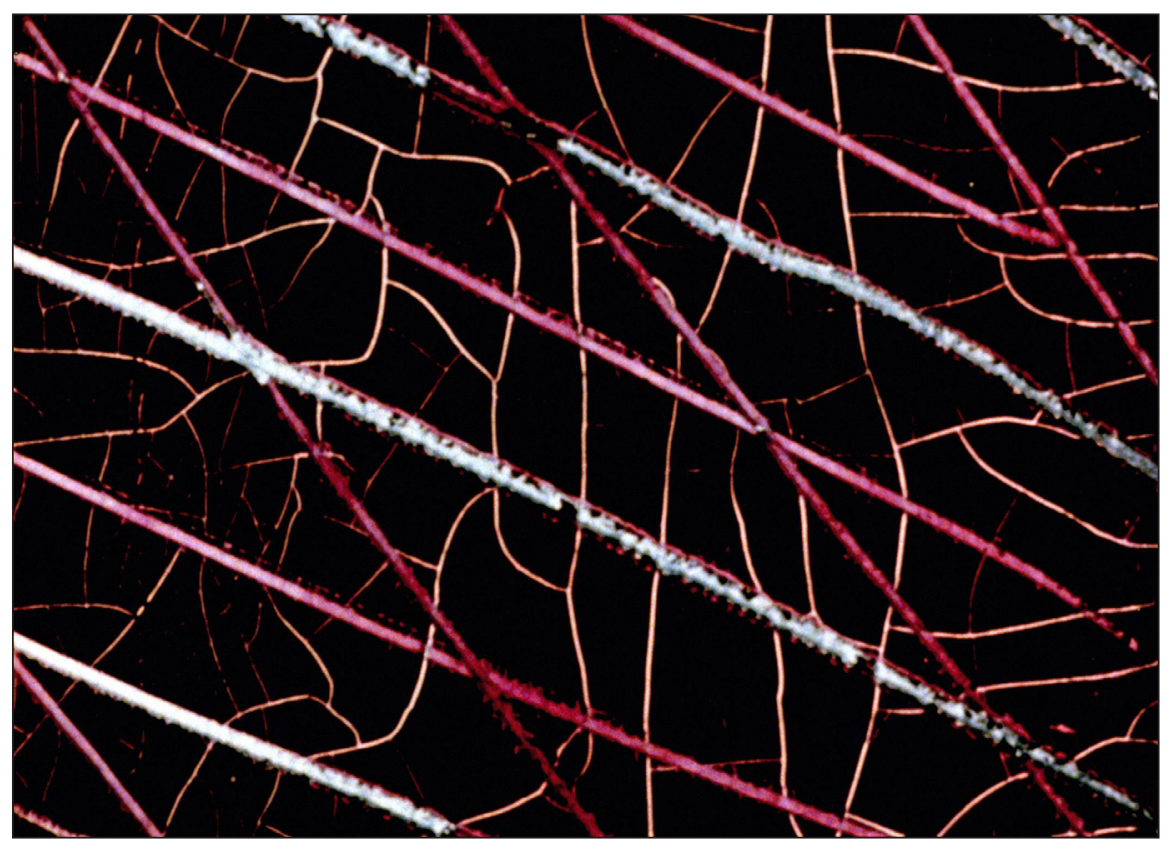

Figure 3. Begone Dull Care (c) 1949 National Film Board of Canada. All rights reserved.

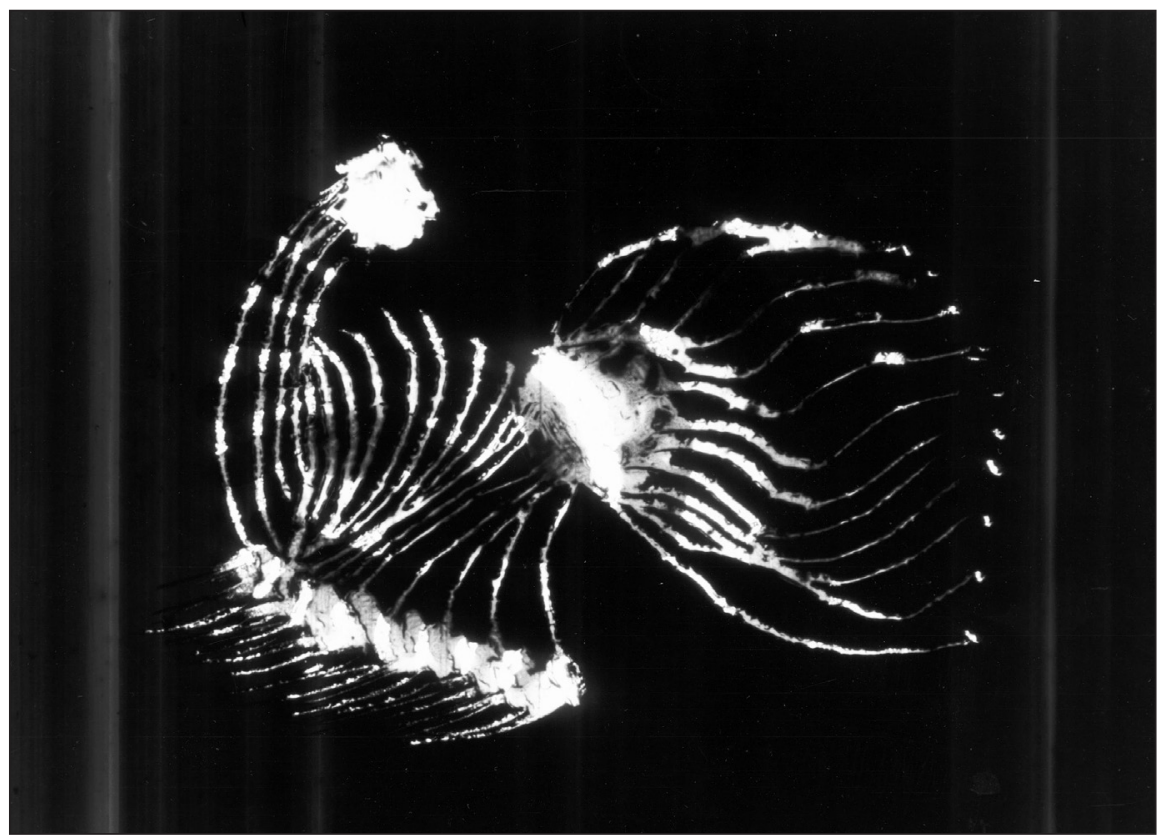

Figure 4. Begone Dull Care (c) 1949 National Film Board of Canada. All rights reserved. 

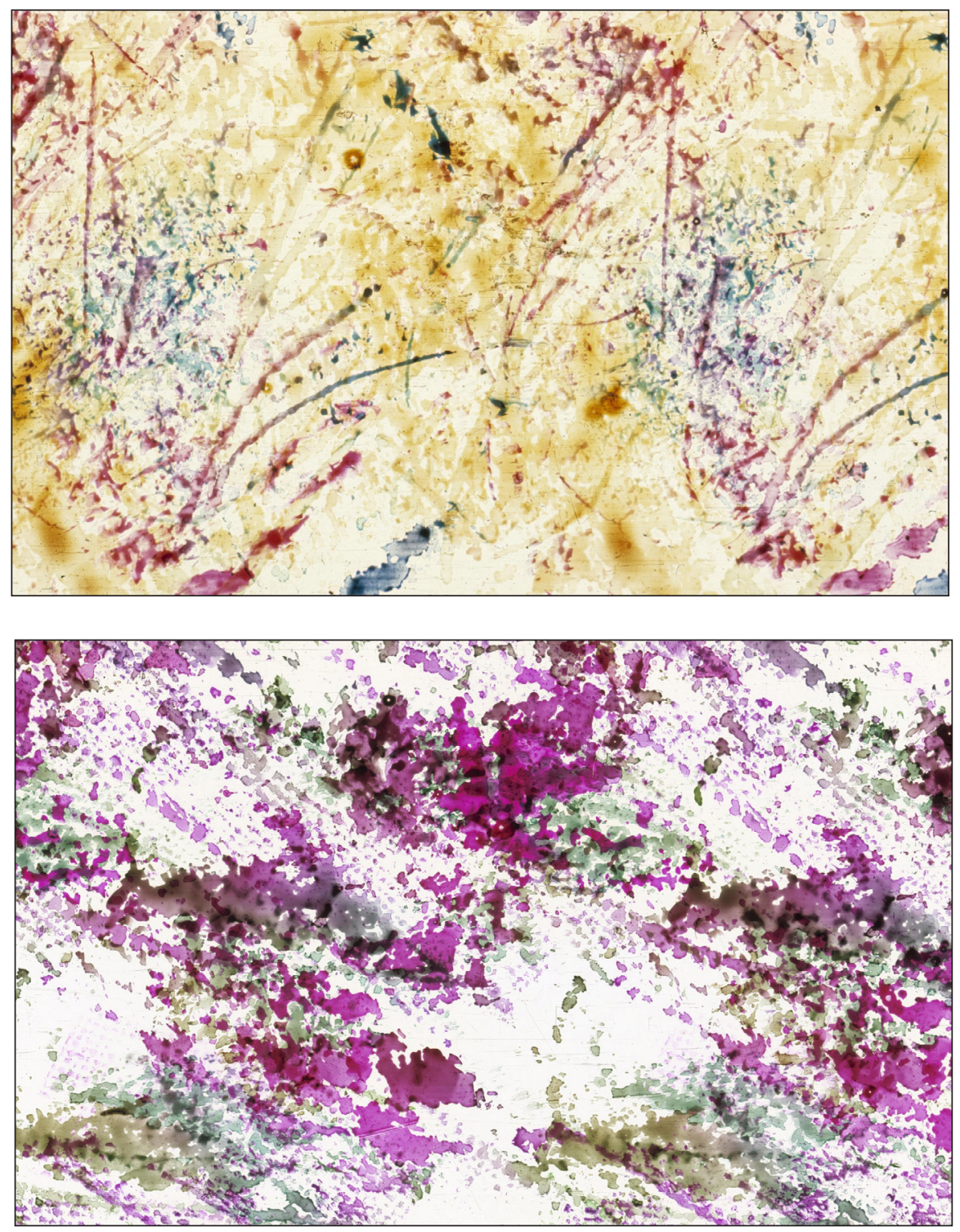

Figures 5 and 6. Begone Dull Care (c) 1949 National Film Board of Canada. All rights reserved.

Some of this frantic busyness resembles veins or blood vessels or the effect one sees when a bright light is shone directed into the eye. Finally, one must remember that McLaren thought of his film cells as paintings. In one moment, they look like slivers of amber that captured mineral deposits and remnants of ancient insects. In the next moment, they look like watercolours or Gerhard Richter-influenced abstractions taken from the walls of any museum.

He says, "I believed filmmaking was like dreaming, although not as free and loose as a dream. By that time I was becoming aware of the need for unity .... 
Progressively, with the years, I've become more conscious of the need for unity, maybe to the detriment of the film" (McLaren 2003, 20).

McLaren is aware of his need to unify this film since he took two forms of absolute disciplines (abstract film and non-representational music) and created a spontaneous conversation between the two. In spite of the abstraction, there is unification in the film that appears visually and audibly, as seen through the combination of image, colour, and music measured by their movement in time. Since neither music nor film can interpret itself, the viewer must decide the meaning presented to us through these abstracted images, and the process of this deduction is discussed in the next section.

\section{The Use of Abstraction in Begone Dull Care}

In most films, the music or soundtrack is laid down after the action of the images has been established, but McLaren and Lambart reverse the process, working with the Peterson Trio to record the music before creating the images. This establishes an idiosyncratic type of animation. But how can a previously recorded soundtrack and a previously designed collection of celluloids appear to coexist in the same space while, at the same time, establishing a relationship for each moment of film time? "The forms of sensory stimuli in works that blend direct animation and jazz can complement each other in ways that seem to 'go together' in a seemingly natural and sensorially satisfying way.... [It is] as if the interior, energetic sensations of listening to music are being manifested in the movements of the animated imagery" (Husbands 2014). The figures on this film do not function with reality in the same manner as a traditional narrative film, which generally has a beginning, middle, and end. With films such as Begone Dull Care and Blinkity Blank (1955), McLaren is attempting to get away from sequential narrative expressed in filmmaking. He pushes for the complete abstraction of images but reclaims them to space and time by purposely representing music visually. 5 The animated shapes become "characters" based on the music, which ranges from dances, skips, and excited jumps to graceful gestures of sombre tones. Begone Dull Care may not represent "real" space, but it does represent "real" time. It is temporal, as most films are, yet the abstract figures dancing madly about seem to evoke another world, one that exists without gravity or in association with a traditional image, text, story, or idea.

McLaren drew inspiration from other abstract films such as Oskar Fischinger's Hungarian Dance No. 5 [Study No. 7] made in 1931 that successfully combined the fusion of visuals and music, to McLaren's liking (McLaren 1977, 6; Melançon 2005), and Len Lye's camera-free visual music animations such as $A$ Colour Box released in 1935 (Mollaghan 2015, 112). Len Lye and Harry Smith's

5 Other artists, such as Hollis Frampton and Michael Snow, incorporated abstraction and minimalism by creating a highly formalist cinema that focused on the medium itself: the frame, projection, and most importantly, time. Similar to the minimalist artist Donald Judd who broke down art into the most bare and essential components, Frampton and Snow repurposed film as anti-illusionist, removing it of any context other than the medium itself. 
No. 1 (ca. 1940) were early exponents of this technique with some of their films (Dobson 2017, 173). What Lye and McLaren share is a "fascination with the irregular vibrations of lines and surfaces 'directly' drawn and painted frame by frame" (Curtis 2003, 175).

Other experimental filmmakers, such as Hans Richter who produced one of the earliest abstract films in Rhythmus 21 (1921), use animation to construct a visual vehicle for the audience as a welcome departure from the newsreels, romances, and dramas that were the bulk of film production in the early 1920 . Others share a common denominator of auditory metaphors and abstract shapes, allowing music to dictate the narrative of the film, as with Richter's Rhythmus 23 (1923) and Eggeling's Symphonie Diagonale (1924). "Their explorations pushed the limits of early film and explored how visual phenomena intersect with concepts traditionally applied to music-rhythm, meter, duration, and tone. For Richter, film, not music, seemed to be the best medium for conveying the art of rhythm" (Stein 2011).

McLaren took note of this particular process and experimented with a sound track for Book Bargain (1937). He continued to make abstract films with technical variations of his drawn-on-film method from Stars and Stripes (1939), Dots (1940), Loops (1940), and Synchromy (1971), and with many of his NFB Films, he drew on or scratched directly onto film, producing a painterly quality, as with Hoppity Pop (1946), Fiddle-de-dee (1947), Begone Dull Care (1949), Blinkity Blank (1955), Short and Suite (1959), Serenal (1959), Mail Early for Christmas (1959), and Lines Vertical (1960). He could create his "visual and aural imagery simultaneously, literally side by side ... giving him instant playback" (Dobson 2017, 93).

When actively listening to music, McLaren, too, imagined a moving, visual equivalent, and thus he began his pursuit of synthesizing film as a visual, temporal art form and music as an aural, temporal art form. ${ }^{6}$ This often led him to abstraction as a means to express movement from objects that do not otherwise move on command. Harking back to Walter Ruttmann's Lichtspiel Opus I, Opus II, Opus III, and Opus IV (1921), McLaren also created large shapes in a single colour that undulate and dance. "The abstract art of music provided a theoretical justification, of one was necessary, for McLaren's involvement in abstract film" (Dobson 2006, 200). McLaren said in a letter to Theo Goldberg in 1973: "Music has had a great effect on me and in quite an old fashioned way since I have found some music 'inspiring.' Certain music had the power of bringing up before my mind's eye certain kinds of moving imagery and some of my earlier films were attempts to put such imagings onto film. But although I may have once thought that I was, if only intuitively, giving a visual

6 During an interview from the film Creative Process: Norman McLaren, McLaren also mentioned being influenced by Hindu music for his animated projects (McWilliams and Dionne, dir. 1990). As a child, McLaren had formal violin and piano lessons and had taken some music theory classes. (Dobson 2017, 89). He invited other noteworthy musicians to produce recorded music for his films: Lines Horizontal (1962) is accompanied by American folk musician Pete Seeger on wind and string instruments, and a John Phillip Sousa march was used in the film Stars and Stripes (1939). He asked Ravi Shankar to produce a compromise between Indian ragas and western music when making the film A Chairy Tale (Dobson 2006, 236.) 
translation of the music in my film in a way that might conceivably have some logical scientific basis, I tend now to consider that naïve" (Dobson 2006, 200).

By reducing his paintings to only shape and colour, his objects could respond to the music with greater fluidity.

There are two kinds of abstract films: one is pure abstract, in other words, the images you cannot recognize them as anything else than what they are. They don't suggest human beings or any kind of creatures, and they don't move with anything but geometric kind of movement, like Lines: Vertical [1960] or Lines: Horizontal [1962] .... On the other hand, there are abstract films where there are objects which are identifiable such as Rythmetic [1956] .... Perform as if they are animals or human beings. Elements take on a personality by virtue of their movement .... Their images or form may be abstract, but their movement is non-abstract or humanly motivated. (McLaren in McWilliams and Dionne, 1990)

However, seeing floating objects dart around, hitting the walls of the frame as if in outer space, could leave some viewers feeling as listless as the objects they are watching. Some viewers are too quick to rely on the familiarity of any apparent visual structure, form, or traditional narrative as something that tells a story in an understandable sequence and may feel disengaged as a result. Comparatively, some listeners are often frustrated when atonal, or especially twelve-tone, compositions are removed from the gravitational pull of a key or tonality. There is a need for a sense of grounding, a root, or foundation from which to compare the relationship between pitches. If this foundation is purposely removed, the listener must find another way to relate to the sounds, which is often an uncomfortable and unspoken action. As a result, many listeners do not take this necessary step and are quick to negatively associate their experience with this music.

McLaren and Lambart's use of abstraction both obscures and unifies the short piece and their own reticence for following any trope of avant-garde filmmakers. David Curtis discusses McLaren's flirtation with the avant-garde genre by manipulating the celluloid itself, the kinetic movements made on a single frame, and his love of phantasmagoria and anthropomorphism (Curtis 2003, 180).7 Curtis continues by saying that McLaren manipulates "the dynamics of movement ... for no other purpose than to generate pleasure through a visual sensation," while his films are non-objective, "anthropomorphic rather than abstract or concrete." The narrative aspects of this film occurs with the assemblage of music and sound; the anthropomorphic images lead the viewer through each of the three movements. The viewer first becomes aware that there is an association between image, colour, and music and then watches this relationship unfold as the dancing objects react specifically to the music. As each tone becomes audible, almost immediately the anthropomorphic images react to the tone. Even though the music was previously recorded, it appears to be heard for the first time in the film, creating a sense of spontaneity. McLaren

7 Also found in William Moritz, "Norman McLaren and Jules Engel: Post-modernists," quoted in Pilling $(1997,104-11)$. 
and Lambart actually timed the abstract images to not only appear but also to interact with the sound of the particular instrument playing. The goal was to stimulate the eye by capturing the rhythmic energy produced by sound and transferring it onto film through abstract images of colour and light.

Another means of unification was associating a sounding motif with a visual shape/colour or by associating a specific instrument to a shape/colour. For instance, the theme of the first movement is tethered to a black background, with white comb shapes responding to the piano. ${ }^{8}$ McLaren links the drums to white lines and sharp, angular shapes, often swapping the black-and-white background to mimic the brushes on the drumhead and simultaneously creating a strobe light effect. Each time we hear the drums during these fast passages, we expect to see white lines. When we hear the bass, McLaren provides us with straight vertical lines that move from side to side, imitating the vertical strings from his instrument. Or appearing at two minutes and fifty-five seconds in, vertical lines reflect the actual tempo of the music as seen with these white lines during an audible break in the music. They steadily get closer together during a two-measure pause in the audible sound and join back together at the downbeat of the next musical phrase. As an interesting side note, many "musicians tend to think about shapes in music moving horizontally, from right to left" (Moshier 2006). McLaren and Lambart painted on a film strip that they pulled vertically over a light source, which may be the reason why most of the abstract objects in Begone Dull Care also move vertically.

As Husbands says, "Directly animated images are rhythmically and graphically able to respond to certain forms of 'undanceable' jazz, such as bebop, with a precision of timing and freedom of movement that no physical dancer could achieve." The nature of the music makes portraying types of jazz such as bebop with dance difficult, and that is why McLaren chose to have animated "lines and shapes [that] are weightless and mercurial enough to match the movements of fluttering fingers and vibrating air" (Husbands 2014). For the more up-tempo piano sections, McLaren painted fluidly along the length of the filmstrip, creating vertical undulating lines that run seamlessly across frames to give a steady sense of nervous wiggle to the frenetic music. He imprinted these lines, shapes, and blobs with human characteristics so that they move with conviction as if they possess their own personality. They are animated in the sense that they are drawn, but they also seem able to move voluntarily. In this manner, they are able to "respond" to the music, if even for a split second, hence why they appear to be anthropomorphic. Each time the sounds of the bass become the focus, as in the slower second movement, we see the straight vertical lines glistening and resembling a spotlight on a stage. The more simplified music allows McLaren and Lambart to show more nuanced spacing and attack, decay, and resonance (Dobson 2017, 204). The cool vibrating white lines in the slow, middle section contrast with the frenzied third movement, and the

8 The comb-like image used in a repeated sequence resembles some of the forms used twentyfive years before by Viking Eggeling in his abstract Diagonal Symphony (1923-4) (Dobson 2006, 203). 
colourful dots and lines found in the first movement return in the fast, boogie-woogie rhythms of the third movement.

Individual shapes seem to match individual notes or chords echoed by the piano, drums, and/or bass. Some shapes appear to create anticipation, such as the three horizontal lines representing a musical break as mentioned earlier; suspense, such as the vibrating vertical strings that sustain on a longer held note before leading to the next pitch; or humour, such as the leaping blobs mimicking the movement of a trained ballet dancer or the flying red bird shape in the outro. McLaren and Lambart created a film that captures a similar sense of jazz with a "kaleidoscopic richness and spontaneity," thereby appearing fresh and unified, encapsulated by the sounds of the three musicians (Dobson 2006, 149). Begone Dull Care is like watching a jazz improvisation during a performance or like "watching the stream of McLaren's unconsciousness unfolding on screen" (Mollaghan 2015, 113).

\section{Conclusion}

Begone Dull Care is especially provocative since it is abstract, yet not truly experimental, and entertaining, but not geared towards mass consumerism. Does his use of animation cause the film to cross into the realm of "entertainment" instead of "art," or are the two mutually exclusive?9 McLaren and Lambart's innovative and experimental approach to film continues to challenge the interpretation of film as an artistic or entertainment designation, causing critics such as David Curtis to ask where one puts Norman McLaren (Curtis in McLaren 1977, 47-53). Curtis, in essence, is stating that McLaren (and Lambart) refuses to fully free their images from a narrative association, which cheapens the experience as it spoon-feeds the audience with easy-to-understand relationships between image, film, and music. However, William Moritz sees McLaren's style of animation (at least for Begone Dull Care) as one that lends itself to new modes of experimental film. Moritz defends McLaren's choice of abstract animation that rejects a shared language of animation similar to that of Disney and Fleischer studio films. Referring also to the work of Grant Wood and Jules Engel, Moritz claims these filmmakers are not attempting to be experimental, but the works of McLaren, Wood, and Engel included "a spontaneous process that linked their natural sense of humor, their conceptual wit and insight, to their disillusionment in the absolute, sacred power of art and the perfectibility of modern art" (Moritz, quoted in Pilling 1997, 110).

McLaren and Lambart continue to baffle critics with their incorporation of abstraction to entertain audiences while blurring other characteristics found

9 Alternatively, one may interpret McLaren's use of animation to relate to his audience as entertainment rather than artistic. His other films were constructed to amuse and educate children or the general public, such as a promotional film of controlled spontaneity reminding Canadians to mail their Christmas cards early, Mail Early for Christmas (1959). He then worked on animated shorts as well as maps for Allied propaganda documentary films, followed by his War Bonds campaign films: $V$ for Victory (1941), 5 for 4 (1941), Hen Hop (1942), and Dollar Dance (1943). 
in both experimental cinema and animated movies. ${ }^{10}$ However, they choose not to be defined by either. Instead, they use techniques within abstraction, narrative, and direct animation to create something new that obfuscates boundaries between cinematic genres. McLaren in particular would advocate the use of film for all of these purposes while especially focusing on education. He believed in the power of film to educate, but not in the sense of a documentary or an ethnographic sense; instead, he explored how we react to movement and music.

McLaren is "someone who loves irony and double coding, rejects the privileged status of high art as opposed to popular art, and feels free to mix elements of past and present, abstract and representational, appropriated and invented, all redefined and revealed to a new audience" (Moritz, quoted in Pilling 1997, 106). He did not establish a representational world inhabited by Disney princesses, nor did he have cowboys and Indians fighting in the Wild West. Instead, he let the object, whether it be a line or a squiggle, stand for itself. Neither the dancing objects nor the film pretend to represent something that it is not. Through his democratic use of sight, sound, and motion as equal parts in works like Begone Dull Care, McLaren and Lambart bent the traditional role of cinema, solidifying his place as a pioneer in animation. This article has provided a brief history of the making of Begone Dull Care and its collaborators, provided a rationale behind the drawn-on animation technique, and given an analysis of music and shapes in the first movement. There are countless avenues in which future scholars can examine McLaren and Lambart's work and contributions to the cinematic landscape; however, it is the hope of this author that there continues to be a growing audience to appreciate Norman McLaren and Evelyn Lambart's unique approach to educate, entertain, and explore the human psyche.

\section{Selected Bibliography}

Barris, Alex. 2002. Oscar Peterson: A Musical Biography. Toronto: Harper Collins.

Berliner, Paul F. 1994. Thinking in Jazz: The Infinite Art of Improvisation. Chicago: University of Chicago Press.

Clark, Andrew. 2001. Riffs and Choruses: A New Jazz Anthology. London: Continuum.

Collins, Maynard. 1998. Norman McLaren. Ottawa: Canadian Film Institute.

Curtis, David. 2003. "Locating McLaren." In The Undercut Reader: Critical Writings on Artists' Film and Video, edited by Nina Danino and Michael Mazière, 174-80. London: Wallflower.

Danino, Nina, and Michael Mazière, eds. 2003. The Undercut Reader: Critical Writings on Artists' Film and Video. London: Wallflower.

10 Curtis (2003, 174-80). Also found in William Moritz, "Norman McLaren and Jules Engel: Post-modernists," quoted in Pilling (1997, 104-11). 
Dobson, Nichola. 2015a. "Dancing to Rhythm of the Music: Norman McLaren, the Body and Performance." Animation Studies Online Journal 10 (2015), https://journal.animationstudies.org/nichola-dobson-dancing-torhythm-of-the-music-norman-mclaren-the-body-and-performance/.

—_. 2015b. "Norman McLaren beyond 100." Animation Studies Online Journal 10 (2015), https://journal.animationstudies.org/ terence-dobson-norman-mclaren-beyond-10o/.

—. 2017. "'bump ... bup ... bup': Aural Innovation in the Films of Norman McLaren." In The Music and Sound of Experimental Film, edited by Holly Rogers and Jeremy Barnham, 89-108. Oxford: Oxford University Press.

Dobson, Terence. 2006. The Film-Work of Norman McLaren, Eastleigh: John Libbey.

Elley, Derek. 1974. "Rhythm 'n Truths: Norman McLaren." Films and Filming 20 (8): 30-6. Reprinted in Canadian Film Reader, ed. Seth Feldman and Joyce Nelson, 94-102 (Toronto: Peter Martin Associates, 1997).

Fleming, William, and Frank Macomber. 1990. Musical Arts and Styles. Gainesville: University of Florida Press.

Furniss, Maureen. 2007. Art in Motion: Animation Aesthetics. Eastleigh, UK: John Libbey.

Husbands, Lilly. 2014. "Seeing Music Move: Norman McLaren's Direct Animation and Jazz." Animation Studies 2.o, https://blog.animationstudies. org $/$ ? $\mathrm{p}=738$.

Jackson, Ronald L., and Elaine B. Richardson. 2003. Understanding African American Rhetoric: Classical Origins to Contemporary Innovations. New York: Routledge.

Jancovich, Mark, ed. 2003. Defining Cult Movies: The Cultural Politics of Oppositional Taste. Manchester: Manchester University Press.

Lees, Gene. 2008. Oscar Peterson: The Will to Swing, 3rd ed., Toronto: Prospero Books.

Lochhead, Judy, and Joseph Auner, eds. 2002. Postmodern Music, Postmodern Thought. New York: Routledge.

Mast, Gerald. 1992. A Short History of the Movies. 5th ed. New York: Macmillan Publishing.

McLaren, Norman. 1949. Begone Dull Care. Montreal: National Film Board of Canada.

- dir. 1951. Pen Point Percussion and Dots (An Introduction to the HandDrawn Sounds of Norman McLaren). Produced by Norman McLaren and Tom Daly. Montreal: National Film Board of Canada.

— 1975. The Drawings of Norman McLaren. Edited by Michael White. Montreal: Tundra Books.

- 1977. Norman McLaren: Exhibition and Films. Edinburgh: Scottish Arts Council.

-2003. Norman McLaren: Selected Films. Harrington Park, NJ: Milestone Film and Video.

_ 2006. “Technical Notes by Norman McLaren (1933-1984).” Montreal: National Film Board of Canada. 
2007. Norman McLaren: The Master's Edition. Dir. Norman McLaren. Montreal: National Film Board of Canada. DVD.

McWilliams, Donald, dir. 2017. Eleven Moving Moments with Evelyn Lambart, Montreal: National Film Board of Canada.

McWilliams, Donald, and Claude Dionne, dir. 1990. Creative Process: Norman McLaren. A National Film Board of Canada Production in Association with the Canadian Broadcasting Corporation and Channel Four Television.

Meeker, David. 1977. Jazz in the Movies: A Guide to Jazz Musicians 1917-1977. London: Talisman Books.

Melançon, Paul. 2005. "Begone Dull Care." Senses of Cinema. Cinémathèque Annotations on Film, 35. http://sensesofcinema.com/2005/cteq/ begone_dull_care/.

Millar, Gavin, dir. 1970. The Eye Hears, the Ear Sees. Montreal: National Film Board of Canada, film.

Mollaghan, Aimee. 2011. "An Experiment in Pure Design: The Minimalist Aesthetic in the Line Films of Norman McLaren." Journal for Animation Studies 6. https://journal.animationstudies.org/aimee-mollaghan-an -experiment-in-pure-design-the-minimalist-aesthetic-in-the-line-filmsof-norman-mclaren/.

. 2015. The Visual Music Film. London: Palgrave Macmillan.

Moritz, William. 1997. "Norman McLaren and Jules Engel: Post-modernists." In A Reader in Animation Studies, edited by Jayne Pilling, 104-11. London: John Libbey.

Moshier, Josh. 2006. “The Music of 'Begone Dull Care.” Jazz:animated. https:// jazzanimated.wordpress.com/2006/07/19/the-music-of-begone-dull-care/.

Orr, John. 1998. Contemporary Cinema. Edinburgh: Edinburgh University Press.

- 2000. The Art and Politics of Film. Edinburgh: Edinburgh University Press.

Palmer, Richard. 2002. A Jazz Odyssey: The Life of Oscar Peterson. New York: Continuum.

Pilling, Jayne, ed. 1997. A Reader in Animation Studies. London: John Libbey.

Pochodowicz, Laura E. 1998. "Begone Dull Care." http://people.wcsu.edu/ mccarneyh/fva/M/Begone Dull Care.html.

Prendergast, Roy M. 1992. Film Music A Neglected Art: A Critical Study of Music in Films. New York, W.W. Norton.

Richard, Valliere T. 1982. Norman McLaren, Manipulator of Movement: The National Film Board Years, 1947-1967. East Brunswick, NJ: Associated University Press.

- 1992. Norman McLaren, Manipulator of Movement. Delaware: University of Delaware Press.

Stein, Jannon. 2011. "Abstract Films from the 1920s: Making Rhythm Visible." Iris. http://blogs.getty.edu/iris/abstract-films-from-the-1920s-making -rhythm-visible/. 
Sukla, Ananta, ed. 2001. Art and Representation: Contributions to Contemporary Aesthetics. Westport: Praeger.

Thompson, Kristin, and David Bordwell. 1994. Film History: An Introduction. New York: McGraw Hill.

Warkentin, Germaine. 1988. "Norman McLaren," in Documents in Canadian Film, ed. Douglas Fetherling, 68-81. Toronto: Broadview.

\begin{abstract}
In 1949 filmmakers Norman McLaren and Evelyn Lambart created the seven-minute, forty-eight-second, animated short Begone Dull Care, filled with abstract images moving in time to the music of the Oscar Peterson Trio. In this three-movement film, McLaren and Lambart use the improvisatory nature of jazz to establish a narrative, allowing the animated shapes to respond and react to the music itself. This article addresses the collaboration between artists and musicians to create such an influential piece and examines the interdisciplinary relationship between music and animation in Begone Dull Care.
\end{abstract}

\title{
RÉSUMÉ
}

En 1949, les cinéastes Norman McLaren et Evelyn Lambart ont réalisé le court métrage d'animation de sept minutes et quarante-huit secondes intitulé Begone Dull Care, à partir d'images abstraites défilant au rythme de la musique du trio d'Oscar Peterson. Dans ce film tripartite, McLaren et Lambart tirent parti de la nature improvisée du jazz pour établir un récit, permettant aux formes animées de répondre et réagir à la musique elle-même. Cet article s'intéresse à la collaboration entre artistes et musiciens dans le but de créer d'une telle œuvre, et examine les relations interdisciplinaires entre musique et animation dans Begone Dull Care.

\section{BIOGRAPHY}

Heather Pinson has earned a PhD in interdisciplinary arts from Ohio University, an MA in musicology from Louisiana State University, and a BA in music from Samford University. At Robert Morris University, Heather teaches courses on art and music history and publishes predominately on popular music, jazz, aesthetics, and race theory. She is the author of The Jazz Image: Seeing Music through Herman Leonard's Photography (University Press of Mississippi), which examines the photographs of African American jazz musicians during the 1950 and 1960s. Other publications include articles in Rock Brands: Selling Sound in a Media Saturated Society, the Encyclopedia of the Blues, and the Encyclopedia of African American Music. In addition to her training as a classical violinist, she performs regularly in the greater Pittsburgh and Ohio area in both popular and classical music ensembles. 